\title{
A CASE OF VERTIGO AND DISTURBANCE OF EQUILIBRIUM DUE TO SUBDURAL HEMATOMA
}

By

\section{T. MUKASA}

From the Department of Otorhinolaryngology Nagasaki University of Medicine

(Director: T. Goto)

The patient was refered to our clinic becaus of disturbance of internal earfunction.

For the past six months he had had the attack of Vertigo, ataxia, vomiting and headache. Syncope was accompanied at the first attack.

On examination, hearing was proved to be within normal limit and vestibular function test also revealed no significant change. The vertigo of the patient was not rotatory type but was the result of instability of his posture due to undetermined cause. Serologytest was positive for syphilis. While examination of cerebrospinal fluid revealed high pressure and pleocytosis, but no xanthochromia was noted.

On angiograms, there was found subdural hematoma in the fronto-parietal region.

The signs aud symptoms were considered due to meningial irritation.

\section{硬脑膜下血腫例における眩暈感並に平衡障碍}

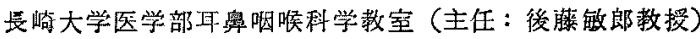

向 等 朝 竞

緒 言

眩最を訴える患者は趣転性の眩最も，浮動性の眑暈 る，立らくらみ(眼前暗黑感) る全て「メマイ」として訴 える.耳鼻咽院科では眩最感が前庭迷路性のものかるる いは非迷路性の他の疾患によるものか明確にしなければ ならない場合が多い、メニエル（1861）が湤烈な眩最に なやんで死亡した例を報告して以来，前庭迷路障害によ

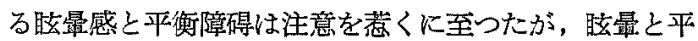
衡障碍のうちにはその発現部位の明らかでないるのが多 くこの解明のためには迷路のみに限らずに広く各種の ものについて全般的にその発現機序を研究することが必 㱠である。

前庭性睹最の定型的のものをメニエル氏症候群に伴引 瞒最と平衡障得とすると，これと鑑別すべき矓最感及び 平衡障碍恃原矣患として化㬩性迷路炎，迷路梅䓯，中毒 性迷路疾患，小脳橋角尰湯，脳血管病，頭部外稘後遗 症，神経症及びメニエル氏病類似疾患之呼ばれるるので ある・
著者は半年前より眩最感，覀心，嘔吐，頭痛を新完治 療をらけ安静にし一時軽快したが再び同様の発作がおこ り，次第に䫓痛が激しくなつて当科を訪れたた患者を経験 した・この例は揄查の結果 subdarale Blutung である ことが明らかになつたものである。かっる病正に伴う眩 最感及び平衡障碍について観察したところを述べて，眩 最及び平衡障碍の鑑別に資したい。

\section{症例}

思者：大○万○ 50 才。 漖油製造工員

主訴：睹最感步行障害, 頭痛

家族暦：父 64 才で胃癌, 兄 52 才で脳溘血で死亡。” その他特記軎項はない。

既往歴：特記すべきことはない、酒は飲まない。

現病歴：昭和 35 年 5 月初旬の夜中, 何等誘因なく突 然意識朦朧となり倒れた（約 15 分）.この時に後㖽部を 打つたよらに思ら，安静にし治療をらけて治つたのでそ の後す仕事を行つていた.7月中旬に悪心，洍吐があ り，盿䰹感（頭がふらふらして足の位置がはつきりしな 
いという〉が括こり，このため歩行が困難となつた。こ の症状は 3 日間持綥したので卧床していた。年の後仕事 は休えでいたが 8 月中旬に再び前と同様な発作が抽こつ た。発作中は覀心，嘔吐のために食欲はない。難聴, 耳 鳴には気付かない，意識障害は 5 月に 1 度あつただけで その後の発作特にはない，発作のない時にも頭痛があ り，最近はとれがひどくなつてきた。発作は突然就こり 前駆と考它られるものはない。

現症：栄咅良，頭痛が激しいためか顔貌はや〉苦悶 状，頭部顔面などに外傷との他異常はみられない，意識 鲜明，呼吸正常, 脈搏整実, 発熱なし, 肺心腹部に所見 なく EKG 子 異常がをい，両側凌蓋腱反射並にアキレ 又腱反射は僅かに六進，上肢の筋腱反射は正常，バビン スキー陰性, 項部強直はないがケルニヒ症候あり.血圧 は 110 70mmHg である.

局所所見：耳鼻領域比異常なく，口唇吉口蓋は正常，

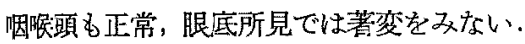

臨床榆查成績：血液一梅毒反応 陽性，赤血球数 405 万，白血球数 4000 , 血液像著変はない，脳瓷䯚液一(臥 位) 初压 $200 \mathrm{mmH}_{2} \mathrm{O}$, 終压 $130 \mathrm{mmH}_{2} \mathrm{O}$ (7cc 採取), Queckenstedt 現象陰性，水栐透明，細胞数 86/3 (淋巴 球), Pandy 反応 $(+)$, Nonne-Apeltl 民応 $( \pm)$, 高 田荒反応 $(+)$ ，総蛋白量 $0.02 \% ，$ 綟 $0.072 \%$ ，尿一蛋白 $(-)$, 糖 $(-)$. 血沈正常.

聴力梌査一表の如くである。耳鳴は訴䍃ない（表 1).

表 1 聴力検查

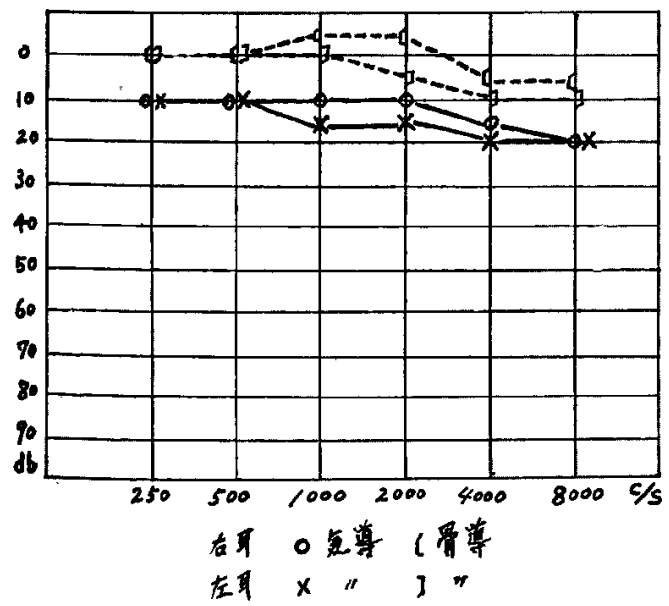

前庭㙨能検查一自発性腿振 及び頭位变換性腿振はな い、ロンペルグ現象（士），Mann's test (t) 右方に倒 わ易い，斜面台検查は開眼では異常なく開眼では体が少
乙摇れるが特に著交を認めない，歩行並に足踏検疽は綬 徐で体が動摇し右方に偏笴するが正常範围である.遮眼 書字検查は正常，指舅試験正常，Adiadochokinese 纴

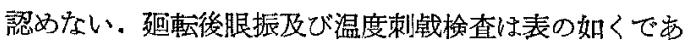
る(表 2,3 )。

表 2 超転後眼振検查

\begin{tabular}{|c|c|c|c|c|c|}
\hline & 方向 & 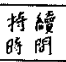 & 大? & 打数 & 炏他 \\
\hline 石迏転 & $\rightarrow$ & $40^{\circ}$ & 大 & 56 & \begin{tabular}{|l|} 
雭心 \\
呕吐
\end{tabular} \\
\hline 后迎檕 & $\leftarrow$ & $35^{\prime \prime}$ & 大 & 63 & $"$ \\
\hline
\end{tabular}

表 3 温度 刺 戟 検 査

\begin{tabular}{|c|c|c|c|c|c|c|}
\hline & 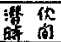 & 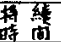 & 才河 & 大き & 打数 & 组他 \\
\hline & K 30 & C 2 & ece & $10^{\prime \prime}$ & & \\
\hline 右国 & $12^{\prime \prime}$ & $65^{\prime \prime}$ & $\rightarrow$ & 中等大 & $5 / 10^{-}$ & \\
\hline 在身 & $13^{\prime \prime}$ & $78^{\prime \prime}$ & $\leftarrow$ & $\prime \prime$ & $7 / 10^{\circ}$ & \\
\hline 漫 & 4 & $c \quad 2$ & oce & $n 10^{-}$ & & \\
\hline 右耳 & $13^{\prime \prime}$ & $62^{\prime \prime}$ & $\leftarrow$ & $"$ & $6 / 10^{\circ}$ & 2 \\
\hline 在耳 & $15^{\prime \prime}$ & $67^{\prime \prime}$ & $\rightarrow$ & ' & $7 / 10^{\circ}$ & \\
\hline
\end{tabular}

(フレンツェル氏鏡による肉腿的钼察)

絽過：入院時には歩行は援徐で酪酊者に似ているが 少し歩く乙頍痛が激しく臥床してしまう，鎮痛削，鎮静 剂を与えるか，脳脊㖶液を採取すると症状は楽になると いう．入院 $l$ 週問目儿脳血管造影を行つた．梅毒区応陽 性であったので 駆梅療法を 開始した１00月に入ると歩 行してもあまり頭痛がしなくなった。

\section{綕括並に考按}

5 月初旬発病前に頭部外傷の既往はなかつた。㜇力梌 查は两耳殆えど正常の聴力像を示した．前庭機能榆査で は Mann's test 陽性で右方に倒れ易い頃向にあつた。 步行は緩徐で酪酊者似似ていた。また盂転刺战中に嘔吐

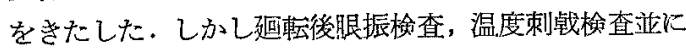
その他の機能検查では異常は認められなからた。

梅毒反心応陽性であつたが，迷路梅毒であわば最初の 眩昱発作である萣度の聴力障害をきた寸盧れが多いので 本例では考克なくて上いと思う．心臓炘見なく EKG にも異常は認められない，高血圧なく，尿検查正常であ つた。

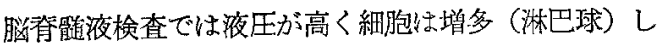
ていた，しかし発熱なく，血沈，胸部し線像とむに正常 であつた。

媨血管造影検查で次のような所見を認めた。 
右脳血管造影：右前大脳釛脈の 左側变位は左前大脳 動脈よりも著明である. 右中大脸動脈の末䊘枝附近に沶 いては著しく内方に变位し，頭蓋外縁との間に3 日月形 の非造影琙を認め, これは Capillary phase, Venaens phase でも同様に認められる (写真).

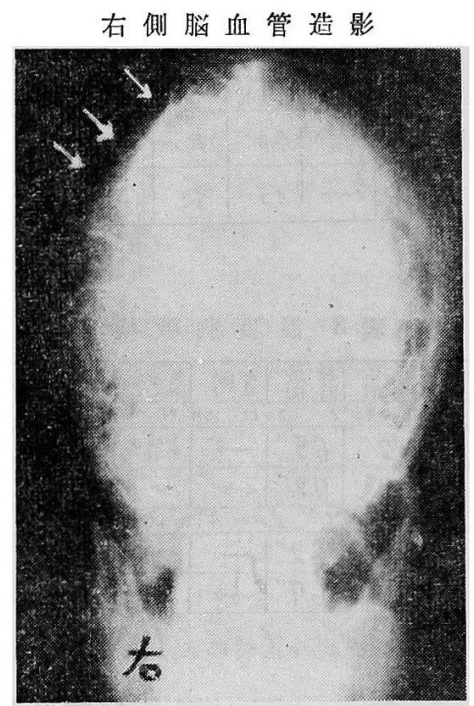

右側前頭頭頂部に血尰を認も

左脳血管造影では異常所見を認めない。

この結果右侧前頭頭頂部の硬脳膜附近に血腫のあるこ とが見出された (図).

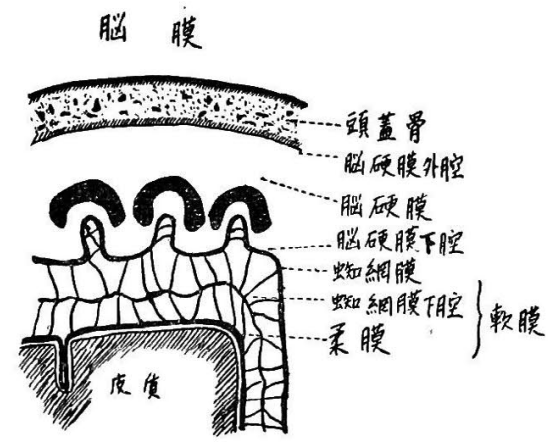

本例の所見からみると硬脳膜下出血, 蜘網膜下出血が

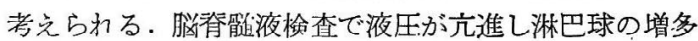
が認められたことは蜘網膜下出血に多く見られる所見で あつて，これは硬脳膜下出血との鑑別の所見となつてい る.キサントクロミーは蜘網膜下出血に多く硬脳膜下 出血では稀である．本例では脳の病巣症状（皮質性症
状)はみられない，何等の誘因なく突然意譩障害をきた して倒れその時に頭部を打つたというが，この原因とし て二つのことが考光られる．即ち硬兴膜下血尰では外傷 と初発症候との間にや〉長い時日が経過寸る場合があ り，このために外傷を原因として考光に入れていない場 合がある. 第 2 は梅毒反応が陽性であるから脳血管に何 らかの変化が持こり脆弱となりこのため破綻し出血し易 くなることである

一硬脳膜下出血，蜘網膜下出血のいら゙れにおいても脳圧 六進が持続的に存在し頍痛, 嘔吐, 隌最などがおこつて くる. 局所症状のないことは出血が徐々に敊こり均等に 拡散するからである・本例では経過中に発熱は一度もな 〈 脳脊歌液が水様透明でキサントクロミ一を呈さない ことは硬脳膜下血腫と考劣るのが妥当のようである.

本症は耳鼻咽喉科では遭遇することの稀な疾患であ る.内科方面では比䡥的多く見られるものと思われるが 生前に何等の病状を示さずに剖検の際に発見すれる例が ある. 本症は硬脸膜, 蝴網膜附近の血管の破綻により, あるいは脳表面の血管の破綻及び脳溢血の洔に出血が脳 室より起る場合などに伴つて起つてくる．原因は不明の ことも多いが一般には外傷，涩精中毒，脳萎縮を伴う慢 性疾患, 出血性素因, 悪性筫血, 白血病, 㙼血病, 鉛中 毒: 高血压, 動脈硬化, 慢性耍炎, 精神的及び肉体的過 労, 出産などが挙げられているが，本症では硬脳膜の梅 毒性血管炎のために起つたものと見做すのが妥当であろ 亏.

\section{結語}

1）本例は眩暴感，步行障害，覀心，嘔昍，頭痛を訴 元内耳障害の氮いで来院した. しかし最初の発作で意識 障害があり眩最感は延転性のものでなく頭がららつき足 の位置がはつきりしない等のものであつた。

2）聴力は殆儿ど正常に 近く耳鳴もなかつた．前庭機 能検查でも著:変を認めなかつた・高血圧なく肺心腹部に も所見が認められなかつた。

3）梅毒反応は陽性であつたが聴力障害のないことか ら迷路梅毒とは思われない。

4）脳脊骴液検查は液圧高く淋巴球の增加, 水様透 明, 蛋:白正常などの所見があつて骾膜炎が疑われたが, 炎症症状を欠いていた。

5) 脳血管造影によつて 右側前頭頭頂部の 硬脳膜附近 に血腫が認められた。

6) 本例に見られる 盿最感及び平衡障碍は硬脳膜下血 
腫（出血性内硬脳膜炎）のためにおこつた脳膜刺㦸症状 と診断した。

$$
\text { 文献 }
$$

1) 白岩俊雄: 蚛蛛膜下腔出血症の一死亡例, 日耳帠, $45,2,187.2)$ 沖中重雄: 内科書, 上巻. 3) 後藤 敏郎：耳番咽喉科学, 上巻. 4) 岩崎秀之：出血性 硬脳膜炎, 神経研究の進歩, 3, 2, 404. 5) Virchow R:
Verh. physik. u. Ges. würzburg 7: 134, 1856. Link. K.H: Traumatische sub-und intradurale B1utung-pachymeningitis haemorrhagica. Veröff. Konstit. u. wehrpath 12: H. 4, 1945.7 7) 佐藤邦夫：蜘 網膜下出血, 耳喉科, 31, 5, 358 .

（原稿到着 $=$ 昭和 35.11 .26 日）

\section{TM式耳鼻治療台}

1. オイルポンブ昇降装，迴転止ヘンドルは側 面にあり操作至便

2. 簡単なる操作により平板状となし手術合とし て使用し得

3. 水道スビットン装固は左右両側いずれイも簡 単仅取付け得

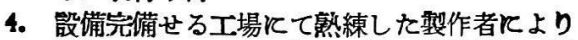
製作せられたるものなるが故に構造極めて精 密且つ堅牢にして体裁優美なり

5. 逢䒾はマホガニー, 赤外線㜔付装

御 注 意

最近 TM 式として粗德製品が大量に 販壳されております弊社製品と御指 定下さい

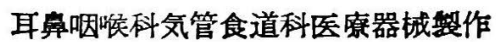

$$
\begin{aligned}
& \text { T.Matui } \\
& \text { 有限会社 }
\end{aligned}
$$

\section{TM医療器松井製作所}

本 社 東京都文京区 湯島二丁目 四番地

電話小石川 (921) 0575・1281 番

出張所景都市東山区東大路松原下ル小島

町一四二 振替口座東京 77400 番

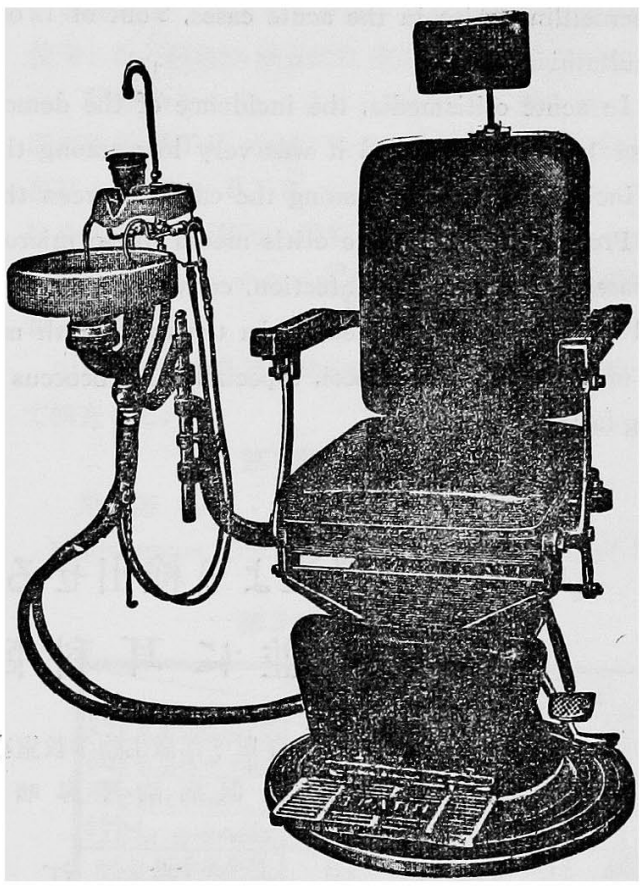

